\title{
Transzeurázsiai közlekedési kapcsolatok nagy- és középhatalmi erőterekben
}

\author{
Trans-Eurasian transport links in great and \\ medium-size spaces of power
}

\author{
ERDŐSI FERENC
}

ERDŐSI Ferenc: kutató professzor emeritus, MTA Közgazdaság-és Regionális Tudományi Kutatóközpont, Regionális Kutatások Intézete, Pécs; erdosi@rkk.hu

KULCSSZAVAK: Kelet-Ázsia, Közép-Ázsia, Kaukázus, Oroszország, Kína, nagyhatalmak, érdekek, vasút, versengés

ABSZTRAKT: E cikk a globális gazdaság két erőközpontja, Európa és Kelet-Ázsia közötti vasúti korridorok, valamint az azokon folytatott logisztikai szolgáltatások létrehozásában, működtetésében, viszonylataik, útvonalaik meghatározásában a 20. század elejétől megnyilvánuló nagyhatalmi érdekekről szól, melyek korunkban már középhatalmi, illetve egyes etnikai csoportok által képviselt érdekekkel is kiegészülnek.

A kettős földrészen (bikontinensen) végigvezetett pályalánc (transzszibériai és európai folytatása) birtokában Oroszország, illetve a Szovjetunió monopolhelyzetet élvezett a transzeurázsiai tranzitszállításokban - mellyel időnként vissza is élt.

Ugyan 1990-ben a kínai és közép-ázsiai hálózat összekötésével formálisan megteremtődött a második transzeurázsiai korridor kialakításának esélye, azonban a TRACECA (Transport Corridor Europe-Caucasus-Asia) programban meghirdetett több mint féltucatnyi országot érintő „új selyemút” tranzitforgalma gyenge az erős természeti, műszaki és politikai szegmentáltsága és az elégtelen fejlesztések miatt. E második korridor csak akkor lehet esélyes versenytársa az oroszországinak, ha Kína létrehozza (az ázsiai középhatalmak által is támogatott) normál nyomtávú (a beltengereket is kiiktató) saját érdekủ vasútvonalát Iránon és Törökországon keresztül.

Ferenc ERDŐSI: research professor emeritus, Institute for Regional Studies, Research Centre for Economic and Regional Studies, Hungarian Academy of Sciences, Pécs; erdosi@rkk.hu

KEYWORDS: East Asia, Middle Asia, Caucasus, Russia, China, great powers, interests, railway, competition

ABSTRACT: This article describes the interests of two power centres of the global economy which are manifested in creating and operating rail corridors, logistics services and setting up routes between Europe and Asia since the beginning of the 20th century. Today it has been complemented by the interests of medium powers and of ethnic groups as well.

The Trans-Siberian Railway, constructed in the early 20th century, acted as the belt of the Russian Empire. It was designed to foster cohesion within the empire as well as to convert the

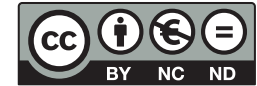


state power previously established in Siberia into a highly efficient economic power. Apart from its economic-regional developmental effect the first trans-Eurasian railway often underscored its military strategic importance as early as 1904.

As an effect of the isolationist policy of the Soviet Union, the traffic of the Trans-Siberian Railway was limited to domestic and international import-export transports for half a century and became available for international transits only in the 1960s. Its container traffic had drastically declined since its 1989 peak only to regain considerable momentum after the year 2000, owing to Chinese cargo.

The termination of the Russian monopoly through the establishment of a second corridor across Central-Asia was in the interest of European, Central- and Eastern-Asian shipping companies alike. The opportunity to sidetrack Russia was formally grasped in 1990 through the connection of the (narrow-gauge) Chinese and the (wide-gauge) Kazakh railway networks. Recognising this potential, the corridor outlined in the 1993 TRACECA agreement - which was based on the common interest of Western-European and Central-Asian business groups - also included the Caspian Sea and the Black Sea which both would be crossed by train ferries.

In recent years, China has become interested in the "New Silk Road" initiative, launched by the USA in 2011, that would eliminate crossing inland seas which are increasing shipping time and costs. China proposed that it would ensure standard-gauge lines throughout the entire corridor for the benefit of interoperability (with the establishment of a new track in Central-Asia and the improvement of the standard-gauge tracks in Iran and Turkey).

The transcontinental transit performance of the TRACECA corridor is as yet very modest as a result of multiple gauge-changes and inland-sea ferry crossings, and the railway chain passing through Central Asia offers only a "quasi" match for the Trans-Siberian Railway. However certain stretches of the New Silk Road prove to be of outstanding significance in the bilateral transport relations of the middle powers (Kazakhstan, Iran, Turkey).

\section{Bevezetés}

Korunkban a világ három gazdasági erőközpontja közül (a tágabb értelemben vett) Kelet-Ázsia súlya megállithatatlanul növekszik. A globális gazdaság földrajzi átrendeződésével első számú erőközponttá lépett elő a Távol-Kelet. E folyamat következményei nem csupán a második és harmadik helyre sorolódó Észak-Amerikát és Európát érintik (bizonyos vonatkozásokban akár drámaian is), hanem a világ többi részét is, mivel az átrendeződés gazdasági, politikai, sőt kulturális téren Afrika vagy éppen Latin-Amerika számára sem közömbös (Erdősi 2010).

Ellentétben a Csendes-óceán által elválasztott Észak-Amerikával, az eurázsiai kontinensen fizikailag nincs akadálya a Kelet-Ázsia és Európa közötti szárazföldi kölcsönös áruáramlásnak, melynek gyakorlatilag a vasúti korridorok a hordozói. Bár ezekre az áruszállításnak mindössze 3,0-3,5\%-a jut, ehhez képest jóval nagyobb a jelentőségük, miután a tengeri úttal szemben fizikailag érzékeny és rövidebb eljutási időt igénylő nagy értékű (jobbára konténeres) szállítmányok megfelelő közlekedési eszköze a vasút (Erdősi 2008).

Miközben a világtengereken a közlekedés szabadságát a nemzetközi jog valamennyi országnak biztosítja, a szárazföldi közlekedés lehetőségét az adott közlekedési infrastruktúrákkal rendelkező országok (politikai viszonyokkal elég gyakran változó) magatartása határozza meg. Az egymással versengő (8-10 ezer 
km hosszú) transzeurázsiai korridorok egyes szakaszai közötti műszaki különbségeken (az interoperabilitás hiányán) és gazdasági környezetén túl a nagy- és középhatalmak (illetve etnikai csoportok) érdekei nagyobb hatást gyakorolnak a forgalom alakulására, folyamatosságára (Erdősi 2013a). E felismeréstől vezérelve jelen cikk (azon felül, hogy általános áttekintést ad a két világgazdasági erőközpont közötti áruáramlás tengerhajózási, vasúti és légi szállítási módok szerinti megoszlását alakító tényezőkről, azok időbeli változásáról) arra a kérdésre összpontosít, hogy a korridorok működésére, teljesítményének ingadozására milyen hatással voltak a legújabb kori történelemben gyakran módosuló birodalmi politikai, katonai stratégiai megfontolások, továbbá hogy a hagyományossal szemben kialakulóban levő új útvonalak milyen motivációk, érdekek „termékei”, és hogy valódi alternatívát képezhetnek-e. Nem utolsósorban azáltal, ha a hatékonyság messzemenő figyelembevételével a legújabb nemzetközi viszonyokhoz igazodóan az érdekeltek hajlandók módosítani (a beltengeri kompszakaszok kiiktatásával) a korridorok Európához közeli szakaszát.

Hazánk külgazdaság politikája a „keleti nyitás” óta szorosabb kapcsolatokra törekszik a Kelettel. E törekvés eredményessége nem kis mértékben azon múlik, hogy milyen módon és mértékben sikerül a hazai nemzetközi közlekedési rendszerünket a jól funkcionáló transzeurázsiai részévé tenni. E szempontból is értékelendők a Kárpát-medencében Oroszország és Kína által szorgalmazott vasúti infrastruktúra-fejlesztések (Bajor, Erdősi 2013), melyek több megválaszolásra váró kérdést is felvetnek a szerzőben - és reményeim szerint a tisztelt Olvasóban is.

\section{A kelet-ázsiai áruáramlás viszonylatai, az egyes szállítási módok versenyadottságai}

Sajátos termelési struktúrája, valamint energiahordozóinak, illetve nyersanyagforrásainak korlátozottsága okán Kelet-Ázsia beszerzési és értékesítési piaca földrajzilag többnyire elkülönül. A legnagyobb tömegű ásványi és más ipari alapanyagok főként Ausztráliából (ércek), a Közel- és Közép-Keletről (olaj), továbbá Dél-Ázsiából, Latin-Amerikából és Afrikából érkeznek, míg a készáru- és félkészáru-kivitel Ázsia más makrorégióin kívül elsősorban Észak-Amerikába, valamint az EU-ba irányul. Szállításszervezési szempontból nem elhanyagolható sem a behozatal és kivitel irányának, sem indulási és célterületeinek chorologikus viszonya, mint ahogyan az export- és importszállítmányok fizikai tömege közötti különbség sem. A távol-keleti feldolgozóipar korszerűsödésével a fajlagos anyagigényesség ugyan lassan csökken, azonban a megtermelt áruk fizikai tömege tovább növekszik, az energiahordozók (kiváltképpen a kőolaj) iránti igény pedig drámai méreteket ölt. Ezért az import és export tömegének mennyiségi viszonyában (a gyakori kisebb kilengések mellett) összességében alig mutatkozik változás; a Távol-Keletre továbbra is az importtöbblet jellemző 
(Erdősi 2013a). Az egyes országok között e téren nagyok a különbségek: az importból a nyersanyagok, élelmezési cikkek, takarmányok és félkész termékek súlya sokszorosan felülmúlja a magas feldolgozottsági fokú, nagy értékủ árukét Japánban, Dél-Koreában és Tajvanon. (Beleszámítva, hogy több különleges fontosságú, nagy fajlagos értékủ exporttermékük - leginkább gépkocsik, elektronikus eszközök - számos alkatrészét távoli beszállítóktól szerzik be.) Kínában viszont tömegét tekintve kisebb arányú az importtöbblet (Statistical Yearbook of China 2012).

Az előzőekből és a földrajzi fekvésből következő számos logisztikai probléma közül e helyen csak kettőt emelek ki:

- a más világrészekkel való kereskedelem teljesen tengeri utakra utaltságát (Ausztrália, Amerika, Afrika, Dél-Ázsia vonatkozásában), vagy túlnyomóan tengerre utaltságát Európa és a Közel-, illetve a Közép-Kelet vonatkozásában, kiegészülve a szárazföldi és a marginális jelentőségű légi szállítással; továbbá

- az áruáramlás irányok szerinti nagy különbsége miatt csak ritkán van mód arra, hogy az exportáruval töltött konténerek, illetve az import(jobbára ömlesztett) áruval teli hajóterek visszáruval feltölthetők legyenek. Ezért az üres konténerek visszaszállítása, illetve az üres vagy félig rakott hajók közlekedtetése a külkereskedelem költségeit nem elhanyagolható módon növelik (RETRACK 2007-2012). Miután Kelet-Ázsia számára Európa elsősorban (készáru-)értékesítési piac, az áruforgalom közel kétharmada kelet-nyugat és csupán bő harmada nyugat-kelet irányú. E drasztikus tömegbeli aszimmetria költségnövelő tényezőként terheli a transz- és periázsiai szállítási rendszereket (Erdősi 2006).

Korunkban a Kelet-Ázsia és Európa közötti áruáramlás oroszlánrészének (95-96\%-ának) a tengerhajózás, kis részének (3-3,5\%-ának) a vasút és alig 1\%-ának a repülőgép a hordozója.

A tengerhajózás a 20. század elejéig abszolút monopóliumot élvezett, de a transzszibériai vasút is csak az 1960-as évektől (fokozatosan) nyílt meg az árutranzit előtt, ahogyan a Szovjetunió a felségterülete feletti átrepülést is ugyancsak késve (a több országgal szembeni diszkriminációt megszüntetve) engedélyezte. (Az Északi-sarkon átvezető kényszerkerülő érzékenyen növelte a légifuvarozási szolgáltatások árát - Erdősi 1998.)

A tengeri szállitás mind a fajlagos szállítási költségek, mind a szállítási útvonal megszakítatlansága, sőt a legutóbbi időkig a mindkét értelemben vett biztonság tekintetében a legelőnyösebb szállítási módnak bizonyult. Zavaró, korlátozó események az indiai szubkontinenst délről megkerülő perikontinentális, majd a Szuezi-csatornán keresztül a Mediterráneumot elérő útvonal egyes szakaszain átmenetileg következtek be. A második világháborúban a német bombatámadások miatt egy évig, majd az Izrael és az arab államok között folytatott háború következtében 1967 és 1975 között volt használhatatlan a világ legforgalmasabb mesterséges vízi útja (Encyclopedia of the Orient 2013). Az utóbbi években a 
Malakka-szoroson kívül a Vörös-tenger bejáratának környékén közlekedő hajókat is veszélyeztetik a kalóztámadások. (Utóbbiak kivédését hatékonnyá tette a nemzetközi haditengerészeti erők megjelenése a térségben.) Ugyanakkor a transzeurázsiai vasutakon is lényegesen javította a szállítmányok biztonságát a fegyveres őrség alkalmazása a szerelvényeken (Erdősi 2005). Jelenleg tehát a kétféle közlekedési mód igénybevételének szállítmányvédelmi kockázata között nincs szignifikáns különbség.

Annál nagyobb hatása van a vasút és a tengerhajózás közötti verseny mindenkori mérlegére a szállítás időigényének, költségének és a logisztikai mozzanatokat is befolyásoló műszaki és szervezési innovációknak. Kelet-Ázsia és Nyugat-Európa partjai között a hajók 2,5-3 hét, az Eurázsián Kelet-Nyugat irányban közlekedő konténerszállító vonatok átlagosan 13-15 nap alatt teszik meg az utat. Az időtakarékosabb, ám költségesebb opcióval főként a fajlagosan az átlagosnál értékesebb és a tengeri útra érzékenyebb (viszont télen a vasutakra jellemző kemény hidegnek is ellenálló) áruk kikötőktől távoli pontok közötti szállításának megtervezésekor élnek.

Ugyan a konténer-irányvonatok menetidejének csökkentését a vasúti infrastruktúra és a vontatás korszerüsítése lehetővé tette, azonban nagyobb kihívást jelentett az országhatárokon eltöltött (föként az országok közötti barátságtalan politikai viszonyok és a forgalomszervezés tökéletlensége, a bürokratikus határ- és vámellenőrzés miatti) anakronisztikusan hosszú várakozási idők minimalizálása. E téren lassú javulás már tapasztalható (nemzetközi összefogással expressz irányvonatok közlekedtetése, egyszerűsített adminisztráció). Azonban a piaci kihívásra a tengeri fuvarozás is hatékony válaszokat keres, mindenekelőtt a szállítmányok épségét óvó, a ráfordításokat mérséklő műszaki újításokkal, a forgalom újszerű szervezési módjainak széles körű alkalmazásával, sőt a jeges-tengeri rövidebb hajózási útvonal igénybevételével (1. ábra).

A szállítmányoknak az 1960-as évektől kezdődő konténerizációja mára rendkívül előrehaladottá vált, a fizikai tulajdonságuknál és értéküknél fogva szóba jöhető áruk 85-90\%-át már speciális építésű konténerhajókon szállítják. Méretük szakadatlanul növekszik, legújabban már 300 méternél hosszabb, 12-15 ezer TEU (1 TEU 20 láb hosszúságú fémkonténer) hordképességü megahajók épülnek kínai és délkoreai hajógyárakban. Ezek a 15-22 méter merülési mélységük miatt azonban csak meglehetősen kevés kikötőbe futhatnak be az egyre gyakrabban 40 lábas egységekből álló rakományukkal, melyek mozgatásához különlegesen nagy teljesítményű darukra van szükség (Erdősi 2006a). Mivel a szállítmányok nagy részének rendeltetési helye nem esik egybe a (természeti adottságuknak, de főként az óriási műszaki fejlesztéseknek, bővítéseknek köszönhető) mély vizű megakikötőkkel, ezért egyre nagyobb teret nyer a már az évtizedek óta alkalmazott hub and spoke (gyüjtő és elosztó) logisztikai rendszer. Az óriáshajók által használt kikötőből számos kisebb (feeder) hajóval szállítják tovább a konténereket rendeltetési helyük felé. Gyakori, hogy az elosztás színteréül szolgáló megakikötő a kiindulási kikötőtől jóval messzebb van, mint a szállítmányt fogadó kisebb kikötő (desztináció), ahová ezért 
1. ábra: Az Arktisz lehetséges hajózásiútvonal-változatai

Potential shiproutes through Arctic waters



Jelmagyarázat: $1 a$ - a part közeli sekély vizü, $1 b$ - a szigetek többségét északról elkerülö, mélyebb vizü, nagyobb hajókkal járható útvonal; 2 - az Északi-sarkon át vezetö (hipotetikus) útvonal

vissza kell jönni. Az ilyen esetekben tehát mellőzni kell a lehető legkisebb földrajzi távolságra törekvést, sőt a költségminimalizáló gazdasági távolság betartása sem lehet cél, hanem kénytelenek a jóval hosszabb és némileg költségesebb „logisztikai távolságon” (Erdősi 2013b) végrehajtani a szállítási feladatot. A TávolKelet és Európa közötti periázsiai útvonalon Hongkong, Szingapúr és Aden mellett az utóbbi időkben megépült mély vizü kikötők közé tartozik Luang Prabang (Malajzia), Augusta (Szicília), Gioia-Tauro (Calabria) stb.

Mindezek a fejlesztések a tengeri konténerforgalom koncentrálódását segítették elő. Azonban a légi közlekedéshez hasonlóan a tengerhajózásban is gyakorlat a megszakítás nélküli (point to point) szállítás az egymástól több ezer km-re levő kikötők között, amikor a tömegterméket előállítók és a távoli nagy piacuk kikötői között közlekedő hajójáratok kapacitásának kihasználtsága biztosított. (Pl. Jokohama és Rotterdam között az autó- vagy Sanghaj és Antwerpen között a számítógép-szállítás - Erdősi 2013a.)

\section{„Földhidak” a kettős földrészen - a transzeurázsiai korridorok}

\section{Helyettesitő vagy kiegészito” szerepben?}

A vizsgált sok ezer km-es távolsági viszonylatokban még a kiváló transzkontinentális műutakon sincs esély a rendszeres és gazdaságos kamionos szállításra, ezért igazából az ikerkontinensen végigvonuló vasútvonalak nyújthatnak a ten- 
geri úttal szemben valós alternatívát. Kérdés azonban, hogy milyen mértéküt, azaz hogy helyettesítő, avagy csupán kiegészítő szerepet képesek-e játszani a szárazföldi korridorok a tengeri útvonalakhoz képest? Az e kérdésre adandó válaszhoz mérlegelni kell a szerepüket befolyásoló tényezőket, nevezetesen a technikai és technológiai teljesítőképességet, a szállítmányok fizikai és értékjellemzőit, a szállítások viszonylatait (a desztinációk között), az együttműködési képességet (interoperabilitást), valamint a természeti, müszaki és politikai okokra visszavezethető forgalmi töréspontok gyakoriságát.

Mindezen szempontok alapján a vasút alapvetően kiegészíti a tengeri szállítást, és bármennyire is fejlettek, jól kiépítettek a vasúti rendszerek, a szállítási feladatoknak csak szűkebb körében képesek helyettesíteni a tengeri szállítást.

\section{Az első transzeurázsiai vasút, az Orosz Birodalom érdekeit szolgáló Transzszib}

\section{Létesítésének indokai, katonastratégiai szerepe és gazdasági jelentősége}

A Moszkvától Szibérián keresztül a Csendes-óceánig (a 20. század elején még csak Mandzsúrián keresztül Port Arthur orosz támaszpont-kikötőig, majd 1917től már kizárólag belföldön Vlagyivosztokig) tartó, a maga korában páratlan műszaki létesítménynek számító megavasút létesítésének legfőbb célja a birodalmon belüli kohézió és a nagyhatalmi pozíció erősítése volt (Erdősi 2010). Az Orosz Birodalom népessége és gazdasági tevékenysége a Keleti-tenger partvidéke és az iparosodó Urál közötti országrészben összpontosult, amelynek a Csendes-óceán-parti hadikikötővel, Vlagyivosztokkal és más part menti kolóniákkal nem volt szárazföldi közlekedési összeköttetése a jobbára (nem szláv) őslakosok által igen ritkán lakott tajgán keresztül, ahol az államhatalmat csak az egymástól távoli, jobbára csak lóháton járható csapások mentén létrehozott kozák helyőrségek, illetve kormányzók képviselték.

A cári udvar felismerte a feltörekvő Japán részéről az orosz Távol-Keletet fenyegető veszélyt, és egyben Szibéria betelepítésének szükségességét is, hogy a lényegében inkább csak a térképen és a joganyagban létező (virtuális) hatalmi tér a tényleges birtokba vétele után nagy teljesítményű gazdasági térré alakuljon át. A mintegy $8000 \mathrm{~km}$ hosszú vasútvonal képletesen a bikontinentális birodalom „nadrágszíjának” szerepét kellett, hogy betöltse. A már az 1890-es években elkezdett építkezés indokoltságát a Japánnal vívott 1904-1905-ös háború elvesztése is igazolta. A kudarchoz ugyanis hozzájárult a Bajkálon túli vonalszakasz hiánya, az utánpótlás-logisztika csődje is. A Transzszib katonastratégiai fontosságát az első világháború és az azt követő polgárháború, majd a második világháború (részben az Amerikából azon keresztül érkező hadianyag, részben a mandzsúriai japán hadsereg ellen 1945 augusztusában vívott „villámháborúhoz" felvonuló 22 szovjet hadosztály szállítása), majd a Szovjetunió és Kína közötti incidensek miatt 1964-től a kínai határ mellett állomásozó milliós szovjet hadsereg ellátásában játszott szerepe is aláhúzta. 
Ugyan a „gőzkorszak” egyik legnagyobb közlekedési infrastruktúrájának létesítése nemcsak az igen kedvezőtlen természeti adottságok (labilis permafroszt altalaj, hosszú havas tél) és a megfelelően motivált és képzett munkaerő hiánya (elítéltek foglalkoztatására ráutaltság) miatt, hanem az óriási méreteket öltött korrupció következtében is a tervezett összeg többszörösébe került, azonban gazdasági haszna mégis megkérdőjelezhetetlen (Westwood 1964). Egyrészt azáltal, hogy a befektetett tőke már az első világháborúig megtérült a vasút szolgáltatásainak ellenértékéből, másrészt mert az amerikaihoz hasonlítható rendkívül gyors regionális fejlődést eredményezett Szibériában (Die Vermehrung... 2001). A cári kormány az európai országrészből a nyomorgó szegényparasztok millióit telepítette át Szibériába, ahol földhöz jutottak. (Ezzel a kormány a szociális indíttatású politikai feszültséget is képes volt ideig-óráig egyes térségekben mérsékelni.) A klimatikus feltételek a rövid tenyészidejü gabonafélék mellett elsősorban a szarvasmarha-tenyésztésnek és tejfeldolgozásnak kedveztek. Olyannyira, hogy pl. a szibériai vaj fogalommá vált a világpiacon (a teljes orosz exportnak értékben csaknem a kétharmadát tette ki) (Metzer 1977). Ezen túlmenően a vasút megjelenésével együtt járt a nagyüzemi szénbányászat kibontakozása, a legkülönbözőbb fémes ércek kitermelése is megtöbbszöröződött, és a vasúti járműjavító (majd gyártó) üzemek létesítésével a műszaki kultúra letéteményesei is megjelentek a vasút mentén.

A szovjet korszakban a Transzszib mentén különösen a vas- és fémkohászatra alapozott nehézipar, valamint az energiatermelés óriásüzemei megtelepülésével, a pályavillamosítás és kétvágányúsítás előrehaladásával megnövelt szállítási kapacitás adta lehetőségekkel hatalmas urbanizált gazdasági tengely jött létre.

A Transzszib (egyes szakaszainak) forgalmát és ezzel a gazdasági tengely súlyát hathatósan növelték az 1930-as évektől megépített, észak és dél felől becsatlakozó vonalak (2. ábra). Közülük kiemelkedett jelentőségével a Turkszib (mely a komparatív előnyök kihasználása érdekében a közép-ázsiai gyapot- és gyümölcstermelő régiókat kötötte össze a szibériai gabonatermelőkkel - Eurasian Land Bridge, 2012). A kelet-szibériai Transzszibtől Mongóliába (majd azon keresztül Kínába) tartó vasút elősegítette a vazallus Mongol Népköztársaság integrálását a szovjet gazdasági térbe (Radnaabasaryn 2000).

Ugyan Kelet-Szibériában a Transzszibtől északra (azzal nagyjából párhuzamosan) haladó Bajkál-Amur vasút építésének célja a térség természeti erőforrásainak hasznosítása volt, valójában a Szovjetunió és Kína közötti (fegyveres incidensekig fajuló) politikai feszültség miatt volt szükség a közös határtól távolabbi, rendkívüli áldozatok árán épített, de ez idáig be nem fejezett vasútvonalra (Erdősi 2005a).

A Szovjetunió felbomlása óta a Transzszib menti gazdasági övezet teljesítménye a termelés és az általa generált szállítás drasztikus csökkenésével kb. az egyharmadára zsugorodott. Azonban az orosz állam bevételét növelő nemzetközi tranzit fejlesztése érdekében megvalósult a Transzszib teljes hosszának villamosítása és kétvágányúsítása (Erdősi 2013a). 
2. ábra: A transzeurázsiai vasúti korridorok

The Trans-Eurasian railway corridors

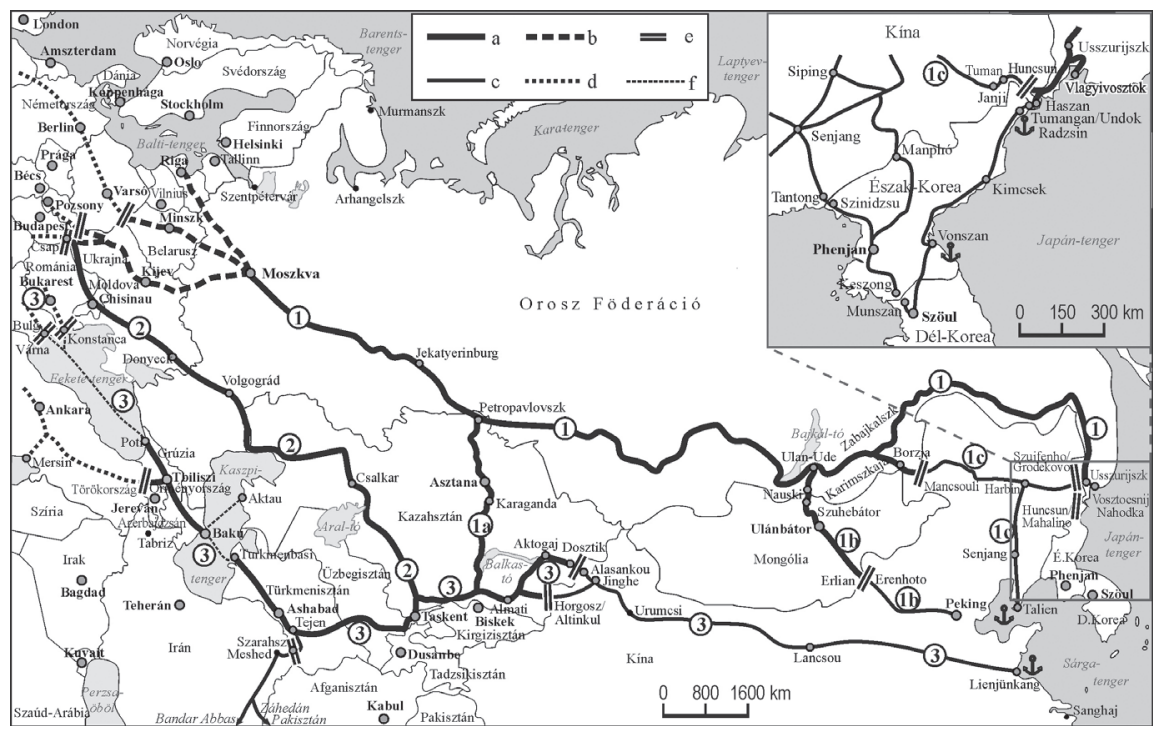

Jelmagyarázat: a - széles nyomtávú pályák, b-széles nyomtávú csatlakozó vasutak Európában, c-normál nyomtávú pályák Kínában és Iránban, d - normál nyomtávú csatlakozó vasutak Európában és Törökországban, e - nyomtávváltás határállomáson, f-tengeri vasúti kompvonalak. 1 - Transzszib törzsvonal, $1 a$ - Transzszib-Kazahsztán, $1 b$ - Transzszib-Mongólia, 1c - Transzszib-Mandzsúria mellékvonal, 2 - Középső korridor, 3 - TRACECA. Kivágat: Észak-Korea-Kína/Oroszország vasúti összeköttetések.

Forrás: Jane’s World... 2010 és több tanulmány adataiból szerkesztette a szerző.

\section{A Transzszib monopolhelyzete a tranzitszállításban (az 1960-1980-as években)}

A szovjet vezetés paranoiája olyan súlyos volt, hogy közel fél évszázadig nem engedélyezte sem az ország légterén, sem a területén átmenő közlekedést. A Transzszib megnyitását a nemzetközi tranzit számára az 1960-as évektől gazdasági és politikai tényezők kényszerítették ki. A Szovjetunió a létfontosságú (gabona, technológia stb.) importjához szükséges konvertibilis valutabevételek növelése érdekében megfelelő szolgáltatási díj fejében továbbította a nemzetközi tranzitszállítmányokat (gépeket, darabárukat és egyre inkább konténeres árukat). E tevékenységet eleinte saját szakosodott vállalata látta el, de később az Orosz Vasutak már külföldi szállítmányozó cégekkel együttmüködve - esetenként vegyes vállalatokat alapítva - végezte e tevékenységét (Erdősi 2008). A transzeurázsiai szállítás lehetősége egy ideig elsősorban Japán és Dél-Korea számára volt nagy fontosságú, miután e két ipari hatalom fejlett elektrotechnikai, műszeripari és más (fejlett technológiai alapokon termelt) termékeinek piaca egyre inkább kiterjedt Európára. Logisztikai megfontolásból a széles nyomtávú vagonokba rakott keleti áruk legnagyobb elosztó desztinációja (kihasználva az azonos nyomtáv előnyét) Dél-Finnországban jött létre, ahonnan főként gyorsjáratú hajókkal, valamint légi úton terítették szét az értékes porté- 
kákat Európa többi országába. Kétségtelen, hogy a (főként a Helsinki konferencia után érzékelhető) politikai enyhülés is hozzájárult ahhoz, hogy a transzszibériai tranzitforgalom mérete az 1980-as évek végén érte el tetőpontját (Lebendiger Verkehr... 1989). (1. táblázat)

Mindemellett a tranzitforgalom meglehetősen rapszodikusan változott, részben a kiszámíthatatlan („húzd meg - ereszd meg”) tarifapolitika, részben a megfelelő konténerszállító vasúti járművek állapota, kapacitása függvényében. A Szovjetunió szétesése után a tranzitforgalom is drasztikusan visszaesett - részben a szolgáltatások megbízhatatlansága miatt. Ezen az Orosz Vasutak a szerelvények védelmével, majd korszerü dél-koreai gyártmányú konténerszállító kocsik, továbbá a nagy (40 lábas) konténerek mozgatására alkalmas daruk és más gépi eszközök beszerzésével, jobb szervezéssel igyekezett változtatni. A forgalom az 1990-es évek végétől ismét lassan emelkedett, de most már a kínai áruk megjelenésének köszönhetően (Kulke-Fiedler 2005).

Oroszország ma is mindent megtesz (és a jövőben várhatóan további hathatós intézkedéseket hoz) a forgalom növeléséért, a monopolszerep megtartásáért. (Most már nem annyira az ebből származó pénzbevétel érdekében, mint inkább a nagyhatalmi tekintély megtartása miatt.) Hogy ez maradéktalanul sikerülhet-e, az alapvetően attól függ, hogy létrejön-e és milyen hatékonysággal működtethető a Transzszib egyelőre csak kibontakozóban levő versenytársa: a Közép-Ázsián keresztül több lehetséges útvonalváltozatban összeköttetést teremto „új selyemút”, a TRACECA-korridor (TRACECA 2015).

1. táblázat: A konténerforgalom alakulása a két transzeurázsiai vasúti korridoron, 1000 TEU Development of Container Traffic in the two Trans-Eurasian Railway Corridors

\begin{tabular}{lcc}
\hline Év & A teljes Transzszib forgalma & $\begin{array}{c}\text { TRACECA } \\
\text { (a Dosztik-Alasankau kazah-kínai } \\
\text { határállomáspár forgalma) }\end{array}$ \\
\hline 1971 & 2 & - \\
1980 & 80 & - \\
1987 & 162 & - \\
1989 & 184 & - \\
1993 & 30 & 0 \\
1997 & 62 & 5 \\
2003 & 126 & 20 \\
2005 & 283 & 100 \\
2008 & 345 & 184 \\
2012 & 420 & $240 *$ \\
* a 2010-tól müködö Horgosz-Altin Kul-Zhetigen kazah-kínai vasúti átmenet forgalmával együtt. \\
Forrás: A szerzö szerkesztése különbözö publikációk (Joint Study 2000; Notteboom, Rodrigue 2011; RETRACK 2012; \\
Söderhalm 2009) és internetes tanulmányok (Current Issues in Shipping..., Kazakhstan and China Develop \\
Cooperation...) adataiból.
\end{tabular}




\section{$A z$ „új selyemút” mint a Transzszib kisebb esélyü versenytársa}

\section{Középső transzeurázsiai korridor a Szovjetunió megszünése után}

Ellentétben az egyetlen állam területén működő Transzszibbel, a többi transzeurázsiai vasúti korridor vonala számos (gazdasági struktúrában, színvonalban, társadalmi viszonyokban, kultúrában és - ami témánk szempontjából leglényegesebb - a nemzeti vasútrendszer infrastruktúra-szabványaiban, vontatási módjában, szolgáltatási rendszereiben is különböző) országot füz fel. A hipotetikus „dél-ázsiai korridor” (amely a tervezet szerint Dél-Kínából Thaiföldön, Mianmaron, az indiai szubkontinensen, Iránon, Irakon és Törökországon keresztül érné el Európát) létesítésének brutális fizikai nehézségei és csillagászati költségei miatt oly mértékben illuzórikus és (a közeli óceáni hajóútra tekintettel) diszfunkcionális, hogy figyelmen kívül hagyható.

A Közép-Ázsiát keresztülszelő vasúti korridor egymáshoz kapcsolódó nemzeti szakaszai viszont túlnyomóan már léteznek, csak éppen néhány körülmény miatt egyelőre nem működnek a teljes hosszában folyamatosan üzemelő korridor aktív szegmenseként. E korridor létesítésének előzményei közül a Kaszpi-tenger keleti partjától a cári Oroszország közép-ázsiai sivatagi/félsivatagi tartományain keresztül majdnem a kínai határig a 19-20. század fordulóján létesített „turkesztáni vasút”, valamint az ahhoz a kaukázusi tartományok vasútjaival kapcsolatot teremtő komphajózási (Baku-Krasznojarszk/Turkmenbasi) útvonal emelhető ki. (Bakuból Dél-Oroszország, valamint Törökország felé a 20. század elején már ugyancsak létezett különböző kihasználtságú infrastruktúra-kapcsolat. A Kína csendes-óceáni partjától Európáig tartó középső korridor leghosszabb (több száz kilométeres) hézaga Nyugat-Kínában csak 1990-ben szünt meg, amikor a Kazahsztánban már korábban Drúzsba (mai nevén Dosztik) határállomásig megépített széles nyomtávú pálya elérte a kínai határállomásig, Alasankauig tartó normál nyomtávú vonalat (Hall 1997). E mozzanat hallatlanul felkeltette a hipotetikus középső korridor valamennyi résztvevőjének sokféle érdektől motivált érdeklődését. Közös nevezőjük Oroszország elkerülésének (ezzel monopolszerepe megtörésének) szándéka volt a kombinált (vasúti/beltengeri) szállítás versenyképes, integrált bikontinentális rendszerének megvalósításával. Kezdeményezői között már kezdetben ott voltak a tenger nélküli közép-ázsiai országok, amelyek a kikötők elérésének megkönnyítésére törekedtek, annak érdekében, hogy csökkentsék a világpiacba bekapcsolódásuk rendkívül magas szállítási költségeit. Ugyancsak erős érdeklődést mutatott e korridor iránt az Európai Unió (Fehér könyv... 2001), főként a távoli posztszovjet országokba, a potenciális piacterületekre eljutásnak különleges fontosságot tulajdonítva. E megfontolások alapján dolgozták ki a nyugati szakértők a TRACECA projektben testet öltött „ú́j selyemút” koncepciót, melynek programját az érdekelt országok az 1993. évi bakui értekezleten írták alá (Erdősi 2009).

A TRACECA útvonalát a szélességi köröket meglehetősen mereven követve, a megteendő távolság minimalizálására törekedve, a hosszú szárazföldi szaka- 
szokat megszakító két beltengeren, a Kaszpi- és a Fekete-tengeren keresztül tervezték meg. E megoldás kombinált szállítási módot igényel, mely igazán csak megfelelő technológia használatával lehet hatékony. A hagyományos vasúti komphajók közbeiktatása megtöri a szállítás folyamatosságát, növeli időigényét (Black Sea Region... 2012).

Miközben a középső korridor keleti szakaszának (Kínán és Közép-Ázsián átvezető) vonala kezdettől rögzített volt, a nyugati szakaszok megszerzéséért több nemzet is verseng. A tengerek által megszakított útvonal esetében Bulgária (Várna), Románia (Konstanca), sőt Ukrajna (Odessza/lljicsevszk) verseng a Fekete-tenger-parti (délkelet-európai) kapuszerepért. A tenger nélküli változat esetében korábban Dél-Oroszország és Ukrajna szerette volna az útvonalat észak felé ívelővé tenni (Ukraine und die... 2007), de később felmerült a Türkmenisztán-Irán-Törökország-Európa változat is. A harmadik („,kompromisszumos”) változatnak az bizonyult, amely csak a Fekete-tenger kiiktatásával számolt, és a Kaszpi-tenger nyugati partjától (Bakuból) Törökország felé tartotta szükségesnek a transzeurázsiai vonatok útvonalának déli irányú áthelyezését. Az utóbbi elképzelés megvalósítása politikai jellegű problémákat vet fel, amelyek megértéséhez szükséges háttérismereteket az alábbiakban foglalom össze.

Az egyik tényezöcsoport a pántürk politikai erók érvényesülése a Kaukázus nemzetközi közlekedési kapcsolataiban. A Kaukázus térsége évszázadok óta az egymással vetélkedő Orosz és Oszmán (Török) Birodalom ütközőzónája volt. A 19. század utolsó évtizedeiben Oroszország már szilárdan uralta e térséget, és elsősorban katonapolitikai megfontolásból megépítette a Kaszpi- és Fekete-tenger kikötőit összekötő Transzkaukázus vasutat (1883). Majd a Törökországba benyomuló hadsereg utánpótlását elősegítendő, a grúziai Tifliszből az örményországi Gümrin keresztül 1899-ben az anatóliai Karsig, majd 1913-ban a további orosz hódítások nyomán Sarikamisig egy további vasút létesült. Az első világháború után Törökország visszakapta a korábban megszállt területeit. Szovjet-Örményországban és az eltérő nyomtávú török vasúthálózaton (az etnikai feszültségekre is visszavezethetően) az 1930-1980-as években a személy- és teherforgalom meglehetősen jelentéktelen volt (BTK, Baku-Tbilisi-Kars Railroad 2008).

Az önállósult kaukázusi országok közötti kölcsönös sérelmek a különféle felek (egy időben Grúzia és Azerbajdzsán) közötti fegyveres konfliktusokhoz vezettek („,bellum omnium contra omnes”), mely Örményország és Azerbajdzsán között pusztító háborúvá eszkalálódott. Ennek során Örményország megszállta a Hegyi-Karabahot, az Azerbajdzsán exklávéjává váló Nahicseván pedig autonómiát kapott. Még ha megalapozottnak tünik is a történelem során számtalanszor bevált „divide et impera” trükk alkalmazása a mögöttes nagyhatalom, Oroszország részéről (orosz-grúz háború 1992-ben, melynek következtében Abházián keresztül megszünt a közvetlen vasúti összeköttetés a két ellenséges ország között), valójában vallási mezt öltött, régi keletű etnikai ellentétek tragikus következményekkel járó felizzásáról volt szó. A türk nyelvcsaládba tartozó azeriek és törökök fogtak össze a térségben senkivel sem rokon örmény 
katolikusok országa ellen. Ugyan az azeriek az iszlám síita, a törökök viszont a szunnita felekezethez tartoznak, a más relációkban (pl. Irakban) véres összetüzésekhez vezető különbségnek a kaukázusi politikai kártyák keverésében nem volt szerepe: a felekezetbeli különbséget felülírta a pántürk politikai összefogás az olaj- és gázexportőr Azerbajdzsán és az arra ráutalt Törökország között. Ennek egyenes következménye lett, hogy az EU és az USA neheztelése ellenére Azerbajdzsánból Grúzián keresztül épült meg - Kars végállomással - a törökországi hálózathoz kapcsolódó új (BTK) vasút. Ezzel megvalósult Örményország teljes kiiktatása a TRACECA-ból. Örményország az elszigeteltségből, külkereskedelmét ért súlyos anyagi veszteségek csökkentése érdekében eredményesen közeledik Oroszországhoz („ellenségeim ellensége a barátom”), másfelől viszont délnyugati szomszédján, a síita iszlám Iránon (Sulfa határállomáson) keresztül vezető (dubai és iráni tőkéből épülő) vasúttal szeretné elérni a Perzsa-öbölben a tengert (Almasion 2014; Iran ready to finance... 2013).

A BTK vasúttal tehát műszakilag létrejött a TRACECA türk érdekeket szolgáló déli változata Törökországon keresztül (3. ábra).

A másik tényezöcsoport a kialakulóban levő kínai gazdasági szupremácia érvényesülése az ázsiai kontinentális közlekedésben.

Kína gazdasági befolyása évezredek óta érvényesült Közép-Ázsiában - föként a selyemúton folytatott kereskedelemmel - a cári Oroszország idején is. Kína „kisugárzásának” véget vetett a Szovjetunió létrejötte, amely az izolacionalista (a határok lezárásához vezető) politikát kombinálta centripetális hatalmi erejének a birodalom (gyepüként is funkcionáló) perifériáira gyakorolt nyomásával.

3. ábra: A TRACECA Kaukázus térségi szakaszának vasútjai Railway projects within the scope of TRACECA in the Caucasian region

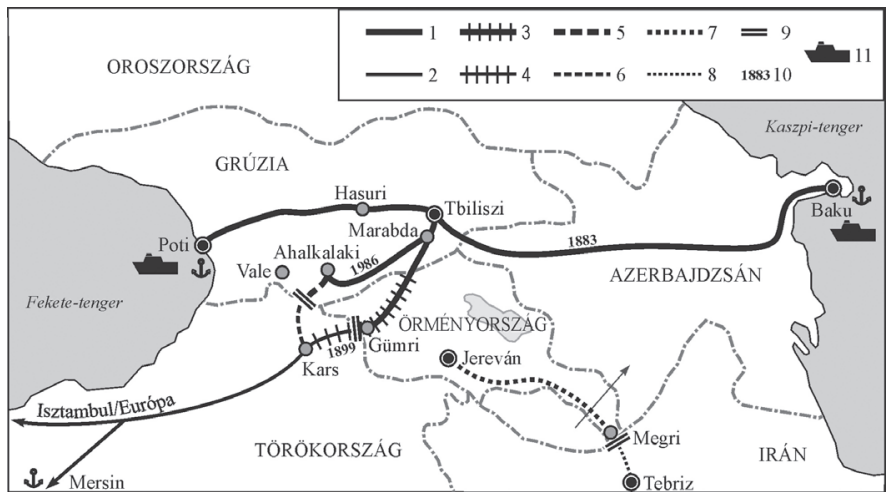

Jelmagyarázat: 1 - müködő széles nyomtávú, 2 - müködő normál nyomtávú, 3 - nem müködő széles nyomtávú, 4 - nem müködö normál nyomtávú, 5 - épülő széles nyomtávú, 6 - épülö normál nyomtávú, 7 - tervezett széles nyomtávú, 8 - tervezett normál nyomtávú vasút, 9 - nyomtávváltás határállomáson, 10 - a vasút elkészültének éve, 11 - vasúti tengeri kompok kikötői.

Forrás: Jane’s World... 2010 és több tanulmány adataiból szerkesztette a szerző. 
Az 1990-es évektől a határ átjárhatóvá vált, amit Kína haladéktalanul ki is használt gazdasági expanziójához. A FÁK (Független Államok Közössége) keretei közötti közép-ázsiai országok a hirtelen elnyert politikai függetlenségük ellenére sem voltak képesek felszámolni a hagyományos kapcsolatokat, a gazdasági/műszaki függőséget Oroszországtól, miközben évről évre erősödött a kínai gazdasági szereplők jelenléte, illetve az oroszokhoz képest többnyire kedvezőbb ajánlatuk beruházóként, kivitelezőként és kereskedőként (Peyrouse 2007). Az így kialakult köztes helyzetben választani kellett a „két úr szolgája” (avagy megkülönböztetés nélküli partnere) és az aszimmetrikus (valamelyik nagy szomszédot előnyben részesítő) opció között. A két nagyhatalomhoz való viszony tekintetében már kezdetben különbségek mutatkoztak az egyes országok között, melyek az idők folyamán módosultak (többek között azzal, hogy egyik-másik az USA felé is nyitott, pl. támaszpontok engedélyezésével).

Mára egyértelművé vált Kína fölénye Oroszországgal szemben Közép-Ázsiában. A korábban már Afrikában bevált „olajért infrastruktúrát” bartermodellt sikeresen alkalmazva kínai vállalatok a kegyetlenül nehéz magashegységi tereppel dacolva nagyszabású vasút- és foutépítésekkel, korszerủ vasúti járművekkel, illetve kedvezményes hitelekkel „fizetnek” az olajért, gyapotért és más nyersanyagokért - fokozatosan kiszorítva a korábban monopolhelyzetet élvező orosz infrastruktúra-építő és jármügyártó cégeket. A Kína és Közép-Ázsia közötti határon a forgalom folyamatos növekedése számos új átkelőhely nyitását tette halaszthatatlanná. A gazdasági kapcsolatok erősödése, az együttműködés új formái a teheráru-forgalom többszöröződésén túlmenően a személyforgalmat is látványosan növelték, nem utolsósorban a határ kínai oldalán létesített hatalmas szabad kereskedelmi övezetekben müködő üzemekbe a kazah és tadzsik oldalról naponta átjáró (olcsó bérü) ,vendégmunkások” tízezreinek köszönhetően.

Kína vasútjai ugyanakkor létfontosságú tranzitszolgáltatásokat is nyújtanak a Közép-Ázsiában létrehozott japán és dél-koreai autógyárak alkatrészekkel való ellátásában, illetve a kész gépkocsiknak a világpiacra való eljuttatásában.

Felmerül a kérdés, hogy Kína kulcsszereplövé válása a transzeurázsiai közlekedésben versenyt vagy együttmúködést jelent a két nagyhatalom között.

Kína ma még infrastruktúra-kényszerből túlnyomóan Kazahsztánon és Oroszországon keresztül közlekedő konténer-irányvonatokkal juttatja el Európába magas árfekvésű műszaki cikkeit. A „világ ipari mühelye” (az „új selyemút” legfőbb tényleges „motorja”) azonban pragmatista politikájához híven a hagyományosnál hatékonyabb alternatív útvonaltervvel állt elő a TRACECA-n belüli töréspontok kiiktatásának, az Európába vezető interoperábilis és folyamatos infrastruktúra megteremtésének szándékával. Kína 120 milliárd USD költséggel a beltengeri kompokat kiiktatva normál nyomtávú vasutat tervez Európába, mely lehetővé tenné a szállítási idő lényeges csökkentését, megszüntetné az átrakások során a szállítmányokban előidézett károkat. Bár nyilvánvalóan saját érdekű vasútvonalról van szó, az új szállítási útvonal előnyeit a partnerországok is élvezhetnék. E nagyszabású terv megvalósításához csak 
Közép-Ázsiában kellene új, önálló normál nyomtávú pályát építeni, de a nyugati folytatáshoz igénybe vehetők lennének a már létező iráni és törökországi pályák - megfelelő műszaki rekonstrukció után. A 2013-tól működő Boszporuszalagút ezzel a két kontinenst összekötő kapocsként a TRACECA részévé válna (Marmary Railway... 2013). Mindezeken felül Kína kész az Európával összekötő nagy sebességű vasút építésére is (China Promotes... 2010).

- A nagypolitikában végbemenő események tükrében meglehetősen ambivalensnek tűnhet a kínai tervezet megítélése. Logisztikai szempontból mindenképpen ésszerű a TRACECA erősen módosított útvonala, nem csupán a komphajózás kiiktatása miatt: hosszú távon is ajánlatos a Kaukázus térség elkerülése az országai közötti viszonyok kiszámíthatatlansága miatt.

- Prognosztizálhatatlan Kelet-Ukrajna sorsa, illetve az ukrán-orosz viszony alakulása. Egyelőre bizonytalannak tűnik a szállítás Közép-Ázsiából Észak-Kazahsztánon keresztül, a Kaszpi-tengert északról megkerülve, dél-orosz és ukrán területeken át széles nyomtávon Délkelet-Európába.

- Mindezekkel szemben a délre kanyarodó változat mellett szól, hogy Kína vasúti építő- és járműipara már jó ideje jelen van a jelentős iráni és törökországi piacon, és ezekkel az országokkal partneri a viszony (ahogyan a közép-ázsiaiakkal is).

Kérdés, hogy Kínának az Oroszországgal elmélyülő gazdasági együttműködése milyen hatással lehet a Transzszibbel szemben versenytársként megjelenő „kínai TRACECA” megvalósítására, illetve leendő forgalmára (Erdősi 2005d). Mindenekelőtt mérlegelendő a kínai külgazdaság alakulása, azaz hogy az állami gazdaságpolitika a jövőben is igen erősen exportorientált lesz-e, vagy pedig a belső fogyasztás jelentősebbé válása és a gazdasági növekedés visszaesése folytán jóval kisebb tömegü áru jelenik meg a korridorvasutakon. Ha nagyjából csupán a mai szállítási kapacitásra lesz szükség, akkor luxus- vagy presztízsberuházásnak látszik a csillagászati összegbe kerülő új interkontinentális infrastruktúra, mivel a kazah és orosz vasutak képesek lennének kielégíteni a kínai igényeket is.

A teljes transzeurázsiai forgalom, illetve a jövőbeni korridorfejlesztések és -működtetések vonatkozásában a másik lényeges kérdés az Oroszország és Kína közötti viszony alakulása, mely jelenleg korrektnek minősíthető, mivel egyfelől az egymásrautaltságból is adódik az együttműködés kényszere, másfelől e viszonyt a békés versengés (a saját érdekeket érvényesítő szó szerinti „különutasság") jellemzi.

Az egymásrautaltság a két birodalom eltérő szerkezetủ transzeurázsiai átmenő forgalmából, illetve a megaméretű kétoldalú kereskedelemnek a szárazföldi és tengeri közlekedéssel szembeni kihívásaiból adódik: Oroszország a tengerentúlra és a kínai iparvidékekre irányuló, túlnyomóan a Szibériából származó, óriási tömegü energiahordozó és nyersanyag mozgatásával járó exportja miatt jobban rá van utalva a Transzszibből kiágazó, a nagy kapacitású kínai ki- 
kötőkbe tartó tranzitvonalakra, mint Kína, amely a tömegében kisebb export készáruinak túlnyomó részét tengeren juttatja el az európai piacokra.

Ezen a helyzeten érdemben aligha változtathat a Kínából Közép-Ázsián keresztül Európába tartó, kínai érdekű normál nyomtávú pályalánc létrehozása a távolabbi jövőben, mivel e vasútvonalra meglehetősen kevés terelődhet az orosz forgalomból. Ellenben az elmélyülő gazdasági együttműködés nyomán növekszik az orosz-kínai árucsere és az orosz export tömege is, ezért Oroszország egyre inkább rászorul az észak-kínai kikötőkre (mint tengeri kapukra) a kedvezőtlenebb helyzetű, illetve környezetű saját kikötői mellett. Más meleg tengeri alternatíva nem jöhet szóba. Ezzel szemben a világ vezető gazdasági hatalmává előlépő Kína egyre eredményesebben törekszik arra, hogy a világpiacok elérése érdekében jó néhány irányban létrehozza és külföldre kiterjedő új vonalakkal diverzifikálja nemzetközi vasúti infrastruktúráját. Ezek közé tartozik, egyelőre csak tervekben, a közel-keleti olaj biztosítása érdekében a magashegységi hágókon és megaalagutakon keresztül vezetendő grandiózus transzpamír vasút, valamint a Pakisztánon keresztül az Indiai-óceánig tartó vasút. Az utóbbi megvalósulásával Kína India „hátába” és az afrikai „új gyarmatok" közelébe kerülne.

\section{Kinek az érdeke a transzkoreai korridor müködése?}

Többszöri kísérlet után még mindig nem állt helyre a két Korea közötti rendszeres vasúti közlekedés, amely lehetővé tenné, hogy a félsziget hosszában a kontinens és Puszan kikötő között megvalósuljon a transzkoreai tranzit.

Világszervezetek tanulmányai, valamint nyugati politikusok szerint az Észak-Koreával határos két nagyhatalom érdeke a transzkoreai vasúti szállítás helyreállítása (Eurasian Land Bridge... 2012). Valójában azonban sem Kínának, sem Oroszországnak különösebben nem füződik a transzeurázsiai folyosó koreai meghosszabbításához érdeke, mert Észak-Koreával szárazföldön, Dél-Koreával pedig jól működő part menti hajózás segítségével kereskednek, és a koreai kikötők „helyzetbe hozásával” az orosz és kínai kikötők számára nemkívánatos konkurens jelenne meg.

A két Korea közötti határ megnyitása a vasúti és közúti közlekedés számára alapvetően a Koreai Köztársaság (a világ 8. ipari hatalmának) érdeke, amelynek exportorientált gazdasága a transzeurázsiai korridorokhoz ma csak tengeren (kínai és orosz kikötőkön keresztül) képes csatlakozni, ezért nagy értékü műszakcikk-exportjának nagy részét kénytelen légi útra terelni. Nagyon valószínű, hogy a határ megnyitása után Dél-Korea számára a Kína felé vezető vasutak lesznek vonzóbbak az általuk elért piacok közelsége és egyben mérete, valamint az érintkező pályák interoperabilitása miatt. Mindezeken túlmenően a határ megnyitása a vasúti közlekedés számára lehetővé tenné a dél-koreai cégeknek, hogy északon megsokszorozzák a bérmunkában történő termeltetést is.

A transzeurázsiai korridorokhoz középhatalmi érdekek is kapcsolódnak. A tágabb értelemben vett Közép-Ázsia országai közül területének nagysága $(2,71$ millió km²) 
és főként tekintélyes nyersanyagbázisa, kitermelőipari teljesítménye, továbbá (a tengerparttal nem rendelkező országok világszövetségének vezetőjeként) nemzetközi kapcsolati rendszere alapján Kazahsztán középhatalomnak tekinthető, melynek a TRACECA valamennyi változatához érdeke füződik. Az Oroszországgal (Nyugat-Szibériával, illetve az Urál déli előterével) összekötő nagy teljesítményü vasutak sokféle szerepet töltenek be. (Többek között a különlegesen nagy méretű eszközöknek a Bajkonurban levő, világűrkutató rakétákat indító állomásra történő szállításához nélkülözhetetlenek.) Ugyan Kazahsztán a posztszovjet (Oroszországot, Ukrajnát, Belaruszt is magába foglaló) Eurázsiai Szövetség tagja, és kétségtelenül sok (gazdasági) szál füzi Oroszországhoz, az utóbbi időben kapcsolata Kínával igen nagy mértékben erősödött (Kazakhstan and China develop... 2012). Ennek fö oka, hogy Kína lett a kazah nyersanyagexport legnagyobb és legközelebbi piaca, továbbá hogy a világpiacra való kijutáshoz a millió tonnákban mért kazah ásványi és egyéb nyersanyagok kiviteléhez a kiemelkedően nagy teljesítményü kínai kikötők biztosítják a legkedvezőbb opciót. Ezen felül Kazahsztán számára az Iránon átvezető TRACECA-szakasz jelentőségét az húzza alá, hogy a dél felé kiágazó pályán elérhető a Perzsa-öböl partvidéke, és a tengerhajózás a Közel-Kelet, illetve az indiai szubkontinens, valamint Kelet-Afrika felé kedvező összeköttetést teremt. Kazahsztán gabonaexportjának túlnyomó része Európa felé irányul, ezért minden eszközzel támogatja a TRACECA tervezett törökországi szakaszának létrehozását is, illetve onnan déli irányban a Földközi-tenger kikötői (elsősorban Mersin) felé kiágazó fővonal rekonstrukcióját (Kazakhstan stimulates grain railway transport, 2010).

A másik középhatalom Irán, mely a TRACECA és az orosz kezdeményezésü, Szentpétervárt Azerbajdzsánon keresztül a Perzsa-öböl iráni kikötőivel majdan összekötő „észak-dél korridor” szállítási potenciáljának a kedvezményezettje. Ma még az iráni tranzit legjelentősebb generálója Közép-Ázsia, de várhatóan a jövőben felzárkózik hozzá az ellenkező irányú TRACECA teljes belföldi szakasza.

A harmadik középhatalom Törökország, melynek alapvető érdeke, hogy kiváló földrajzi fekvését kamatoztatva közlekedési összekötő kapocs szerepre tegyen szert Ázsia és Európa között. Ebben az országban a nagy teljesítményű közlekedési infrastruktúra (nagy sebességű vasút, autópálya) kiépítése már folyamatban van, ami megkönnyíti a TRACECA nyugati szakaszának idevonzását. A tengerszorosokon (Boszporuszon, Dardanellákon) történő, súlyos forgalmi nehézségekkel és környezetkárosítással járó észak-dél irányú tengeri áruáramlás, valamint a kibontakozó kelet-nyugat irányú szárazföldi korridor Törökországot a jövőben tekintélyes nagyregionális közlekedési fordítókoronggá avathatja (Erdősi 2014).

\section{A világpiac közlekedési elérhetösége Magyarországról. Orosz-kínai versengés hazánkban?} Hazánk külgazdasága számára kardinális kérdés a világpiacok elérése a közlekedési infrastruktúrák igénybevételével, illetve fejlesztésével (Erdősi 2005b). E szempontból különös jelentősége van a szóba jöhető tengeri kikötőknek (miu- 
tán elkótyavetyéltük a Duna-tengerjáró flottánkat!), valamint a transzszibériai korridorokhoz való csatlakozásnak.

Kossuth már a reformkorban létfontosságúnak tartotta a hazai külkereskedelem érdekében a megfelelő kikötő létrehozását. Erre utalt a sokszor idézett jelmondata: „Tengerhez magyar!” Ki is épült a rivális osztrák Trieszt közelében Magyarország emblematikus kikötője, Fiume (Erdősi 2005c).

A maradék Magyarország számára a felszólítás nem vesztett időszerűségéből, azonban felmerül a „Hol?” kérdése. Tengeri külkereskedelmünk nagyobb része már évtizedek óta az északi-tengeri belga, holland és német megakikötőkön keresztül áramlik. Szolgáltatásaik kiemelkedő minősége, megbízhatóságuk vonzerő, amely felülírja a távolság tényezőjét a szállítmányozási döntésekben. A hazánkhoz és a külföldi piacaink egy részéhez jóval közelebbi Rijeka (Fiume) harmadlagos jelentőségü a magyar külkereskedelemben, még Konstanca és Koper is megelőzi.

Magyarország tengeri kikötőhasználati stratégiája a 20. században többször is változott. Az 1970-1980-as években az új montenegrói kikötőt favorizálta a magyar kormány - eredmény nélkül. Később, az 1997-ben továbbfejlesztett páneurópai közlekedési hálózatban szereplő (Budapestről induló) V/c. folyosó a dalmáciai Ploče kikötőjébe tart, de (számos ok miatt) a magyar külkereskedelem alig használja. Ezzel szemben a periferikus fekvésű, ráadásul távolabbi Konstanca ügyes üzletpolitikával, a távol-keleti partnerekkel kialakított együttmúködéssel képes volt lényegesen növelni forgalmát Magyarországgal is (Erdősi 2008).

Magyarország az ukrán határon (Kijeven és Moszkván keresztül) csatlakozik a Transzszib európai folytatásához. A kétféle nyomtáv hatalmas átrakóövezet létrehozását tette szükségessé Záhony térségében az 1950-1970-es években, mely egyben az elmaradott északkeleti régiónk egyik fejlesztési központjává vált, több ezer munkahelyet biztosítva. Az utóbbi években azonban az Orosz Vasutak az érdekelt országokkal együttműködve tervet dolgozott ki a széles nyomtávú pálya Pozsonyig (egyes változatok szerint Linzig) történő meghosszabbítására, Budapesten vagy Szlovákián keresztül. Megvalósítása esetén a Záhony térségében történt korábbi hatalmas beruházások teljesen elvesztenék értéküket, és le kellene mondanunk a Záhonnyal kapcsolatos további területfejlesztési célú tervekről (Bajor, Erdősi 2013). Az ukrajnai konfliktus miatt azonban beláthatatlan időre lekerül a napirendről a megvalósítás.

A magyar és szerb kormánnyal Kína egyezményt írt alá a Budapest-Belgrád-vasútvonal teljes rekonstrukciójáról $(160 \mathrm{~km} / \mathrm{h}$ maximális sebességű vonatok számára). A dokumentumokból azonban nem derül ki, hogy csupán a személyszállítás meggyorsítása-e a cél (a ma csak kevés utast számláló vonalon), vagy valamelyik TEN-T folyosó részeként a teheráru-szállítási kapacitás növelése is. Nem világos, hogy miért éppen e szakaszt választották ki a kínaiak. Elvileg feltételezhető, hogy a folytatásában levő Belgrád-Bar-, vagy Belgrád-Konstanca-vasútvonal kiépítésével a kínai külkereskedelem érdekeit szolgáló, a Kárpát-medencét valamelyik beltengeri kikötővel összekötő vasútvonalra van szüksége az érdekelt üzleti köröknek (Budapest-Belgrád vasútvonal... 2014). 


\section{Összefoglaló következtetések}

Az Európa és Kelet-Ázsia közötti kereskedelemben a termelési szerkezet változásával növekszik a szállítási költségre kevésbé érzékeny, viszont a perikontinentális hosszú tengeri utat fizikailag nehezen tűrő, magasabb (hozzáadott) értékű áruk aránya. $\mathrm{E}$ tendencia tovább növeli a vasúti korridorok jelentőségét a globális gazdaság két erőközpontja közötti szállításokban. Vonalvezetésük, teljesítőképességük és tranzitvolumenük az alapvetően nagy- és középhatalmak érdekeit követik.

A nemzetközi tranzit számára az 1960-as évektől megnyitott transzszibériai korridor monopolhelyzetet élvezett, amit a Szovjetunió ki is használt. 1990-ben a kínai és kazah vasúthálózat összekötésével formálisan megteremtődtek az oroszországival szemben alternatívát képező, az orosz monopolhelyzetet kikezdő új vasúti korridor létrehozásának feltételei. Valójában azonban az EU által támogatott (a TRACECA programban manifesztálódott), Közép-Ázsián és a Kaukázuson keresztül Európába tartó „új selyemút” nem volt képes az időközben továbbfejlesztett interoperábilis Transzszib versenytársává válni a féltucatnyi ország határátkelőinek műszaki és adminisztratív töréspontjai miatt.

Egyre kisebb az esélye a TRACECA nyugati szakaszán az eredeti vonalvezetés tarthatóságának; részben a Kaukázus tágabb térségében a pántürk politika érdekérvényesítő képessége, részben a beltengerek kiiktatásának szándéka, továbbá a délkelet-európai kikötőkapukért folytatott verseny miatt. A sokszereplős, számos bizonytalansági tényező által terhelt középső transzeurázsiai korridor akkor lehetne életképes, ha müszakilag egységes pálya vezetne a kínai kikötőktől Közép-Ázsián, Iránon és Törökországon keresztül Európába (a beltengeri komphajózást is feleslegessé téve).

E feladat megoldására csak Kína képes és hajlandó. A kínai gazdasági nagyhatalom jelenléte és befolyása oly mértékben növekszik Oroszország rovására, hogy esetleg a további nyugati irányú expanzió eszközeként megvalósíthatja a tervezett normál nyomtávú vasutat (akár nagy sebességü változatban is). E terv mögé három érdekelt középhatalom (Kazahsztán, Irán, Törökország) is felzárkózott. Kína szerepét a kettős földrészen áramló tranzitban még hangsúlyosabbá teheti kikötői vonzerejének rendkívüli erősödése. Bár Kína a Távol-Kelet és Európa közötti szárazföldi tranzitban felzárkózhatna Oroszországhoz, feltételezésem szerint nem kívánnak változtatni a mai korrekt viszonyukon, mivel annak alapját egyfelől a gazdasági szerkezetbeli sajátosságok miatti együttmüködés kényszere, másfelől a békés versengés jellemzi.

Magyarország ázsiai külgazdasági kapcsolatai szempontjából kardinális kérdés a transz- és perieurázsiai logisztikai rendszerekhez kapcsolódás módja és iránya. E szempontból azonban nehezen értelmezhetők és értékelhetők az orosz és kínai érdekből tervezett vasútépítések hazánkban. 


\section{Irodalom}

Almasion, M. (2014): The Southern Armenia Railway - Transportation infrastructure in Armenia: Part III. http://www.thearmenite.com/newsdesk/southern-armenia-railway-transportation-infrastructurearmenia-part-iii/ (Letöltés: 2014. október 8.)

Bajor, T., Erdősi, F. (2013): Alternative routes between the Far East and Europe (with special regard to the foreign trade of Hungary). Institute for Regional Studies, Hungarian Academy of Sciences, Pécs (Discussion Papers; 92.)

Black Sea region needs ferryboat services http://www.railwaypro.com/wp/?p=9888 (Letöltés: 2012. December 18.)

Budapest-Belgrád vasútvonal: hónap végére kész a terv. 2014. június 6. http://www.mno.hu/ kulfold/budapestbelgrad-vasutvonal-honap-vegere-kesz-a-terv-1230841 (Letöltés: 2014.július 21.)

China promotes its transcontinental ambitions with massive rail plan. - http://www.thetranspor politic.com/2010/03/09/china-promotes-its-transcontinental-ambitions-with-massive-railplan/ (Letöltés: 2012. május 18.)

Die Vermehrung der Leistung. DVZ, 2001. április 6.

Encyclopedia of the Orient http://lexicorient.com/cgi-bin/eo-direct-frame.pl http://i-cias.com/e.o/ suez_can.htm (Letöltés: 2013. április 16.)

Erdősi F. (1998): A légi közlekedés általános és regionális földrajza, légiközlekedés-politika. I. kötet. Malév Rt., Budapest

Erdősi F. (2005): Oroszország, mint a transzeurázsiai logisztika főszereplője. Navigátor, 4., 30-31.

Erdősi F. (2005a): Oroszország nemzetközi közlekedési infrastruktúráinak kényszerei, globális és regionális szerepei. Tér és Társadalom, 1., 1-20.

Erdősi, F. (2005b): Hungary in the European transport space. In: Barta, Gy., G. Fekete, É., Szörényiné Kukorelli, I., Timár, J. (eds.): Hungarian spaces and places: Patterns of transition. Centre for Regional Studies, Pécs, 220-235.

Erdősi F. (2005c): „Tengerre magyar” - de hol? Tranzit, 7., 32-34.

Erdősi F. (2005d): A közlekedés néhány súlyponti kérdésének gazdaság- és katonapolitikai háttere Ázsiában. In: Pap N. (szerk.): Ázsia politikai földrajza. Alexandra, Pécs, 37-72.

Erdősi F. (2006): A kínai árudömping tengeri szállítási infrastruktúrái. Navigátor, 9.,26-32.

Erdősi F. (2006a): Globalizáció és világrészek közötti óriás áruszállító eszközök. A Földrajz Tanítása, 5., 9-14.

Erdősi, F. (2008): Global and regional roles of the Russian transport infrastructures. Hungarian Academy Sciences Centre for Regional Studies, Pécs (Discussion Papers; 69.)

Erdősi F. (2009): Kelet-Európa közlekedése. Dialóg Campus, Budapest, Pécs

Erdősi F. (2010): Közlekedésföldrajz. In: Tóth J. (szerk.) Világföldrajz. Akadémiai Kiadó, Budapest, 313-596. (Akadémiai Kézikönyvek)

Erdősi F. (2013a): A közeledő Távol-Kelet: A transzeurázsiai közlekedési kapcsolatok jelene és jövője. IDResearch Kft., Publikon, Pécs

Erdősi F. (2013b): Távolságfogalmak értelmezése és alkalmazásuk. Tér - Gazdaság - Ember, 2., 27-50.

Erdősi F. (2014): Törökország kulcsszereplővé válik-e az eurázsiai tranzitban? Közlekedéstudományi Szemle, 1., 31-43.

Eurasian Land Bridge (2012): http://en.wikipedia.org/wiki/Lanzhou-Xinjiang_Railway (Letöltés: 2013. január 24.)

Fehér Könyv. Európai közlekedéspolitika 2010-ig. Európai Bizottság, Brüsszel, (2001) [COM 2001/370.]

Hall, P. (1997): Motoren des globalen wirtschaftlichen Wettbewerbs. Előadás az „Auf dem Weg zu einer gesamteuropäischen Politikstrategie“ c. EU Bizottság konferencián. Berlin, 1998. április 27. Hauptrichtungen sowie betriebliche und technische Parameter der Schnell- und Hochgeschwindigkeitsstrecken der Länder Osteuropas im Europa-Asien Verkehr. Zeitschrift für OSShD, 6., 9-17.

Iran ready to finance construction of its part of railway to Armenia. http://www.raillynews.com/2013/iranready-finance-construction-part-railway-armenia-minister/ (Letöltés: 2013. június 26.)

Jane's World Railways 2010-2011. http://www.jwr.janes.com (Letöltés: 2012. február 4.) 
Kazakhstan and China develop cooperation in the railway transportation sector (2012): http://www.rzdpartner.com/news/2012/06/16/377831.html (Letöltés: 2013. január 19.)

Kazakhstan stimulates grain railway transport (2010): http://sinfin.net/railways/world/kazakh.html (Letöltés: 2012. február 4.)

Kulke-Fiedler, C. (2005): Totgesagte leben länger Transsiberische Eisenbahnmagistrale. DVZ, 17.

Lebendiger Verkehr am Transsib. DVZ, 1989. június 9.

Marmaray Railway Engineering Project, Turkey - Railway Technology, 2013 http://www.railwaytechnology.com/projects/marmaray/ (Letöltés: 2014. október 7.)

Metzer, J. (1977): Some economic aspects of railroad development in Tsarist Russia. Arno Press, New York

Nakhchivan Autonomous Republic. http://www.nakhchivan.az/portal-en/index-22.htm (Letöltés: 2012. február 16.)

Notteboom, T., Rodrigue, J-P. (2011): The next box wave - can containerisation reinvert? TOC Europe, Antwerpen http://www.people.hofstra.edu/geotrans/eng/ch1en/appl1en/suez_alternatives.html

Peyrouse, S. (2007): Economic aspects of the Chinese-Central Asia Rapprochement. Silk Road Paper. Central Asia-Caucasus Institute Silk Road Studies Program

Radnaabasaryn, R. (2000): Die mongolische Eisenbahn steht vor einem Jubileum. Zeitschrift der OSShD, $1-3$.

RETRACK (Reorganization of transport networks by advanced rail freights concept). An integrated EU-Project. Potential for Eurasia land bridge corridors \& logistics developments along the corridors. May 2007 - July 2012 https://www.tno.nl/media/2825/report_potential_eurasia_ land_bridge_rail-corridors_final_25042012.pdf (Letöltés: 2012.január 21.)

Söderholm, E. (2009): Container transport in Finnish-Russian Railway Connection. In: VR Group: Annual report 2008. http://www.vrgroup.fi/attachments/.../VR_vsk_Eng.pdf

Statistical Yearbook of China, 2012.

The Baku-Tbilisi-Kars Railroad and its geopolitical implications for the South Caucasus (2008): http://www.criaonline.org/5_5.html (Letöltés: 2011. december 8.)

TRACECA website. http://www.traceca-org.org (Letöltés: 2012. július 17.)

Ukraine und die neue türkische Eisenbahnlinie. DVZ, 2007. február 20.

Westwood, J. N. (1964): A history of Russian railways. Allen and Unwin, London 